\title{
Common diagnosis at an unusual age - pulmonary oedema in a toddler
}

\author{
Leopold Simma, ${ }^{1}$ Thomas J Neuhaus ${ }^{2}$
}

${ }^{1}$ Emergency Department, Children's Hospital Lucerne, Lucerne, Switzerland ${ }^{2}$ Department of Pediatrics, Children's Hospital Lucerne, Lucerne, Switzerland

\section{Correspondence to Dr Leopold Simma, leopold.simma@luks.ch}

Accepted 29 September 2018

\section{DESCRIPTION}

A 15-month-old toddler presented to the emergency department $(\mathrm{ED})$ with a history of fatigue, rhinitis and reduced oral intake. The medical history was remarkable for diarrhoea (Enterohaemorrhagic Escherichia coli (EHEC), Shiga toxin) positive haemolytic uremic syndrome ( $\mathrm{D}^{+}$-HUS) 3 months ago with microangiopathic haemolytic anaemia, thrombocytopenia, renal failure and hypertension. When HUS was diagnosed, he had a blood pressure of $117 / 82 \mathrm{~mm} \mathrm{Hg}$, anuria over 18 hours and a platelet count of $110 \times 10^{9} / \mathrm{L}$ with fragmentocytes on blood film without evidence of complement dysfunction. The patient had come off dialysis after 1 month with persistent impaired renal function (peak creatinine $300 \mu \mathrm{mol} / \mathrm{L}$, on discharge 205 $\mu \mathrm{mol} / \mathrm{L}$, estimated glomerular filtration rate (eGFR) 10 and $15 \mathrm{~mL} / \mathrm{min} / 1.73 \mathrm{~m}^{2}$, respectively). He was on regular amlodipine, calcitriol and sodium bicarbonate. Parents reported normal urine output. Clinical examination showed respiratory rate $62 / \mathrm{min}$, no recessions, heart rate $154 / \mathrm{min}$, blood pressure $122 / 98 \mathrm{~mm} \mathrm{Hg}$, pulse oximetry $100 \%$ and normal temperature. Lung auscultation revealed bilateral inferior crackles; heart auscultation was normal except for a louder second heart sound. Liver was not palpable and peripheral oedema was absent. Chest X-ray, blood count and serum chemistry were ordered.

Imaging (supine) shows marked bilateral perihilar interstitial opacities, Kerley B lines on the left lateral inferior lung, no effusions and normal

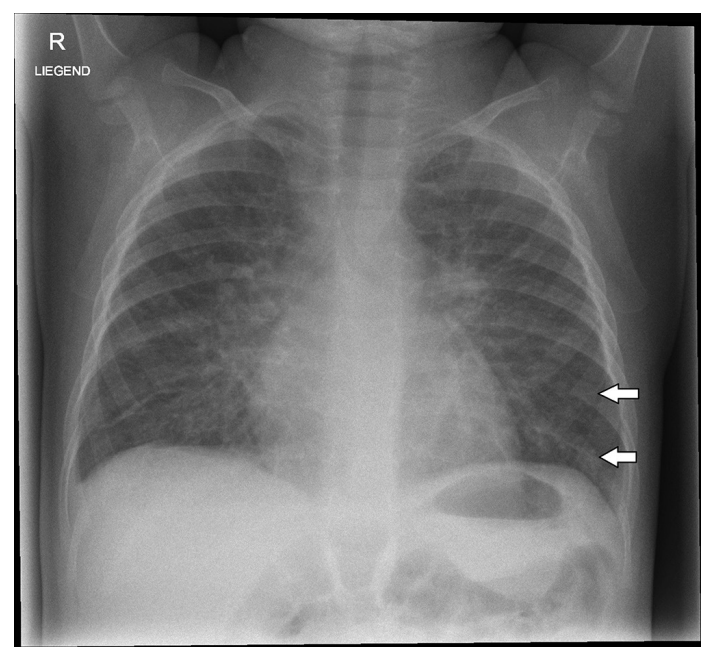

Figure 1 Chest X-ray supine, arrows indicate Kerley B lines. heart size (figure 1). Laboratory results indicated anaemia (haemoglobin $7 \mathrm{~g} / \mathrm{dL}$ ), elevated serum creatinine $(259 \mu \mathrm{mol} / \mathrm{L}$, normal <31, eGFR $12 \mathrm{~mL} /$ $\left.\mathrm{min} / 1.73 \mathrm{~m}^{2}\right)$ and mild hyperkalaemia $(5.6 \mathrm{mmol} / \mathrm{L})$. The patient was diagnosed with pulmonary oedema due to fluid overload secondary to renal failure and transferred for ultrafiltration and dialysis to a tertiary centre.

Non-cardiogenic pulmonary oedema can occur secondary to near drowning, postintubation, ${ }^{1}$ trauma or transfusion, neurogenic pulmonary oedema, ${ }^{2}$ renal failure, drugs or inhaled toxins. ${ }^{3}$

HUS has an incidence of 1.9-2.9 cases per 100 000 children age $<3$ to 5 years in industrialised countries but is much higher in Latin America (10-17 cases per 100000 children in Argentina). ${ }^{4}$ Pulmonary oedema can occur in a small fraction of hospitalised patients. ${ }^{5}$

Overall, pulmonary oedema is rare in the setting of a general paediatric ED.

\section{Learning points}

Pulmonary oedema in children presenting to the general paediatric emergency department is extremely rare.

- Treatment of pulmonary oedema is supportive and based on the underlying cause.

Contributors $L S$ and TJN were treating physicians and drafted the manuscript.

Funding The authors have not declared a specific grant for this research from any funding agency in the public, commercial or not-for-profit sectors.

Competing interests None declared.

Patient consent Parental/guardian consent obtained.

Provenance and peer review Not commissioned; externally peer reviewed.

\section{REFERENCES}

1 Oswalt CE, Gates GA, Holmstrom MG. Pulmonary edema as a complication of acute airway obstruction. JAMA 1977;238:1833-5.

2 Tasaka K, Matsubara K, Hori M, et al. Neurogenic pulmonary edema combined with febrile seizures in early childhood-A report of two cases. IDCases 2016;6:90-3.

3 Bell D, Weerakoddy Y, 2017. Non-cardiogenic pulmonary oedema (mnemonic). https://radiopaedia.org/articles/non-cardiogenicpulmonary-oedema-mnemonic-1 (Accessed 29 Mar 2018).

4 Fakhouri F, Zuber J, Frémeaux-Bacchi V, et al. Haemolytic uraemic syndrome. The Lancet 2017;390:681-96 https://doi.org/.

5 Balgradean M, Croitoru A, Leibovitz E. An outbreak of hemolytic uremic syndrome in southern Romania during 2015-2016: Epidemiologic, clinical, laboratory, microbiologic, therapeutic and outcome characteristics. Pediatr Neonatol 2018:pii: S18759572(17)30739-8 [Epub ahead of print 8 May 2018]. 
Copyright 2018 BMJ Publishing Group. All rights reserved. For permission to reuse any of this content visit http://group.bmj.com/group/rights-licensing/permissions.

BMJ Case Report Fellows may re-use this article for personal use and teaching without any further permission.

Become a Fellow of BMJ Case Reports today and you can:

- Submit as many cases as you like

- Enjoy fast sympathetic peer review and rapid publication of accepted articles

Access all the published articles

- Re-use any of the published material for personal use and teaching without further permission

For information on Institutional Fellowships contact consortiasales@bmjgroup.com

Visit casereports.bmj.com for more articles like this and to become a Fellow 